\begin{tabular}{|l|l|l|l|l|l|}
\hline J. Tek. Ling & Vol. 12 & No. 3 & Hal. 241 - 250 & Jakarta, September 2011 & ISSN 1441-318X \\
\hline
\end{tabular}

\title{
KAJIAN PEMANFAATAN LIMBAH PADAT INDUSTRI PENGOLAHAN RUMPUT LAUT SEBAGAI MEDIA KULTUR MIKROALGA CHLORELLA SP.
}

\author{
Wage Komarawidjaja \\ Peneliti di Pusat Teknologi Lingkungan1 \\ Badan Pengkajian dan Penerapan Teknologi \\ wkwidjaja@scientist.com
}

\begin{abstract}
Abstrak
Penelitian ini bertujuan mencari alternatif limbah organik sebaga bahan baku pembuatan media tumbuh mikroalga Chlorella sp, dimana bahannya melimpah, mudah diperoleh dengan harga lebih kompetitif. Beberapa literatur menyebutkan bahwa rumput laut banyak tersebar di perairan laut Nusantara dan memiliki kandungan nutrien (makro dan mikro) yang tinggi, sehingga limbahnya pun diperkirakan masih mengandung unsureunsur yang dibutuhkan untuk pertumbuhan mikroalga. Hasil analisa nutrien pada limbah padat rumput laut, menunjukan kandungan mikro nutrien yang tinggi, kecuali unsur nitrogen $(N)$ dan posfor $(P)$ yang tersedia relatif rendah, namun masih layak digunakan sebagai media mikroalga. Hasil uji pemanfaatan limbah industri pengolahan limbah rumput laut (LR) dan limbah rumput laut yang sudah diperkaya dengan unsur N (LRP) dibandingkan dengan media F/2 Guillard (FG) menunjukan bahwa limbah rumput laut LRP dapat dimanfaatkan sebagai media kultur mikroalga yang ditunjukan oleh tingkat kepadatan dan laju pertumbuhan mikroalga lebih baik dibandingkan dengan media FG maupun LR (LRP>FG $>$ LR). Dari hasil pembahasan, dapat disimpulkan bahwa media kultur asal limbah proses pengolahan rumput laut LRP membuktikan bahwa limbah organic dari proses pengolahan rumput laut dapat digunakan sebagai bahan baku pembuatan mediam tumbuh mikroalga, khususnya Chlorella sp.
\end{abstract}

kata kunci: mikroalga, nutrient, media tumbuh, limbah organik, rumput laut

\begin{abstract}
The aim of this study was to determine an alternative of raw material for microalgae Chlorella sp culture media from organic waste where the material is abundant, easily obtained with more competitive prices. Some report mentions that a lot of seaweed scattered archipelago contain high macro and micro nutrients that utilized as a raw material of food industries and produce huge organic solid waste. The solid waste was estimated to still contain elements required for the growth of microalgae. A nutrient analysis of seaweed solid waste showed a high content of micro-nutrients such as cuprum (Cu), molibdat (Mo), zincum ( $\mathrm{Zn})$, cobalt (Co), mangan (Mn) dan boron (B) except for the nitrogen $(N)$ and phosphorus $(P)$ which is available is relatively low, but still adequate for use as a culture media of microalgae. In order to fulfil this objective, three sets of culture media in triplicate were setup. The first set was filled with seaweed organic solid waste $(L R)$, the second set was filled with $L R$ and that has been enriched with elements of $N(L R P)$, the third contained medium F/2 Guillard (FG). The results of the study showed that the LRP medium can be used as a microalgae culture media indicated by the density and growth rate of microalgae is better than the microalgae
\end{abstract}


density in the FG media and $L R$ ( $L R P>F G>L R$ ). Base on he results of the study, it can be concluded that $L R P$ as culture media from organic waste of seaweed processing industry can be used as raw material for the manufacture of microalgae culture media, especially for Chlorella sp.

keywords: microalgae, nutrient, growing media, organic wastes, seaweed

\section{PENDAHULUAN}

\subsection{Latar Belakang}

Mikroalga Chlorella sp. adalah salah satu biota yang hidup melayang di permukaan air dan pergerakannya lebih banyak dibantu oleh pergerakan arus. Dengan daya adaptasi yang tinggi terhadap lingkungan dan kemampuan pertumbuhan yang relative cepat, maka mikroalga ini menjadi alternative pertama dalam proses penyerapan gas $\mathrm{CO}_{2}$ pada fotobioreasktor ${ }^{1,2)}$

Hal ini sejalan dengan pendapat Chiu S Y (2007) yang menyatakan bahwa mikroalga dapat digunakan secara efisien dalam penyerapan $\mathrm{CO}_{2}$ karena dapat tumbuh dengan cepat serta siap untuk digunakan pada suatu sistem enjiniring seperti Fotobioreaktor ${ }^{3)}$. Alasan lain adalah karena meskipun jumlah biomassa mikroalga hanya $0.05 \%$ biomassa tumbuhan darat, namun jumlah $\mathrm{C}$ (karbon) yang dapat digunakan dalam proses fotosintesis adalah sama dengan jumlah $\mathrm{C}$ yang difiksasi oleh tumbuhan darat ( 50-100 PgC/th $)^{4}$.

Memelihara dan memanfaatkan kultur mikroalga dalam fotobioreaktor sebagai penyerap gas $\mathrm{CO}_{2}$, membutuhkan media tumbuh yang mengandung berbagai senyawa organik seperti nitrogen $(\mathrm{N})$, posfor $(\mathrm{P})$, mineral dan vitamin dalam fotosintesis yang murah, mudah dan berdaya saing tinggi untuk memproduksi mikroalga.

Dengan demikian, pemanfaatan limbah organik baik sebagai bahan substitusi maupun sebagai bahan baku formula media kultur mikroalga adalah merupakan pertimbangan yang bijak, mengingat hasil penelitian pemanfaatan limbah organik dari limbah tambak udang, limbah industri perikanan dan limbah domestik menunjukkan manfaat yang besar bagi perkembangan mikroalga disatu sisi dan memperbaiki kualitas lingkungan sebagai manfaat yang lain ${ }^{5,6)}$.

Mikroalga pada dasarnya memanfaatkan berbagai senyawa organik terutama pada perairan yang tercemar senyawa organik mengandung $\mathrm{N}$ dan $\mathrm{P}$ bersama $\mathrm{C}$ dalam fotosintesis. Oleh karena itu, kultur mikroalga dalam limbah cair akan tumbuh dengan baik dan sekaligus berperan positif dalam upaya pengolahan limbah cair, seperti terjadi pada air buangan kolam budidaya udang yang mengandung bahan organik dengan konsentrasi tinggi dapat dimanfaatkan untuk kultur mikroalga Skeletonema costatum dan Chaetoceros cocoarctatus co, $^{7,9)}$.

Dengan pertimbangan bahwa, Industri agar telah lama berkembang di Indonesia dimana bahan baku utamanya adalah rumput laut yang berasal dari kekayaan laut Nusantara, maka limbah padat dari proses pengolahan rumput laut dipilih sebagai alterntif bahan baku media kultur mikroalga. Menurut Kim (2008) dalam Triwisari dkk (2009), limbah industri rumput laut ini dapat mencapai $65-75 \%$ dari bahan baku segar yang diolah. Jumlah yang sangat besar ini sering terbuang begitu saja tanpa ada pemanfaatan lebih lanjut yang dapat meningkatkan nilai tambahnya ${ }^{10}$.

Limbah industri rumput laut berpotensi sebagai sumber bahan baku alternatif pembuatan media kultur mikroalga. Rumput laut berdasarkan jenisnya mengandung protein yang beragam, berkisar antara $5-70 \%$ berat kering, tetapi kandungan lipidnya rendah berkisar antara $1-5 \%$ berat kering. Sedangkan kandungan mineralnya 
mencapai $36 \%$ berat kering, yang terdiri dari unsur makro ( $\mathrm{Na}, \mathrm{Ca}, \mathrm{Mg}, \mathrm{K}, \mathrm{Cl}, \mathrm{S}$ dan $\mathrm{P}$ ) dan unsur mikro (I, Fe, Zn, Cu, Se, Mo, F, $\mathrm{Mn}, \mathrm{B}, \mathrm{Ni}$ dan $\mathrm{Co}$ ). Demikian juga kandungan provitamin A, vitamin C dan Vitamin B12 cukup tinggi yang tidak ditemukan pada vegetasi darat ${ }^{7}$.

\subsection{Proses Fotosintesis dan Nutrien}

Mikroalga atau ganggang renik adalah organisme tumbuhan yang berukuran sangat kecil dan hanya dapat dilihat menggunakan mikroskop. Seperti ganggang pada umumnya, alga mikro juga hidup, tumbuh dan berkembang melalui proses fotosintesa yang melibatkan hara (nutrien), sinar matahari dan air $\left(\mathrm{H}_{2} \mathrm{O}\right)$.

Mikroalga atau ganggang renik yang hidup didalam air disebut fitoplankton. Ahli menyebutkan bahwa fitoplankton adalah organisme-tumbuhan sangat kecil (mikroskopik) yang hidup melayang, mengapung didalam air dan memiliki kemampuan gerak terbatas ${ }^{7,8,9}$.

Seperti ganggang yang lain, fitoplankton tumbuh dan berkembang dari hasil fotosintesis yang tergambar seperti pada Gambar 1. Proses tersebut mengisyaratkan bahwa kehidupan dan pertumbuhan fitoplankton di alam sangat tergantung pada kandungan nutrient dan $\mathrm{CO}_{2}$ dalam air serta enerji matahari.

Di Indonesia, proses fotosintesa bagi fitoplakton lebih banyak dipengaruhi oleh nutrient/hara, karena dalam badan air kandungan $\mathrm{CO}_{2}$ secara umum cukup tinggi, dan sebagai negara tropis maka sinar matahari sangat berlebihan.

Nutrien adalah elemen kimia penting yang dibutuhkan fitoplankton untuk tumbuh dan berkembang. Secara alamiah meskipun sebagian besar hanya dibutuhkan dalam jumlah sedikit (nutrien mikro), namun untuk pertumbuhannya fitoplankton memerlukan paling sedikit 19 macam nutrien. Fitoplankton memerlukan nutrien makro $(\mathrm{C}, \mathrm{H}, \mathrm{O}, \mathrm{N}, \mathrm{S}, \mathrm{K}$, $\mathrm{P}$, dII) dalam perbandingan tertentu, sehingga kekurangan salah satu dari unsur tersebut akan menghambat pertumbuhannya ${ }^{7}$.

Nitrat $\left(\mathrm{NO}_{3}{ }^{-}\right)-\mathrm{N}$, Ammonium $\left(\mathrm{NH}_{4}^{+}\right)-\mathrm{N}$ dan orthofosfat $\left(\mathrm{PO}_{4}^{-3}-\mathrm{P}\right)$ adalah bentukbentuk nutrien yang siap digunakan oleh fitoplankton berklorofil dalam proses fotosintesa ${ }^{7,8,9)}$.

Sebagaimana diketahui bahwa pertumbuhan fitoplankton di perairan sangat dipengaruhi nitrogen dan fosfor. Dibandingkan dengan karbon, hidrogen dan oksigen; fosfor dan nitrogen adalah kecil kuantitasnya hingga di perairan umum kedua unsur ini sering dianggap sebagai faktor pembatas bagi pertumbuhan fitoplankton. Lebih spesifik telah diketahui pula bahwa fosfor adalah unsur hara yang sering menjadi pembatas pertumbuhan fitoplankton di perairan tawar, sedangkan nitrogen sering menjadi pembatas pertumbuhan fitoplankton di perairan pesisir dan lautan ${ }^{7}$.

\subsection{Tujuan dan Sasaran}

Kegiatan penelitian ini bertujuan untuk mendorong: pemanfaatan potensi limbah industri rumput laut sebagai bahan baku alternatif pembuatan media tumbuh mikroalga,

\section{METODOLOGI}

\subsection{Pelaksanaan Kegiatan}

Kegiatan ini dilaksanakan di Puspiptek Serpong, pada Laboratorium Balai

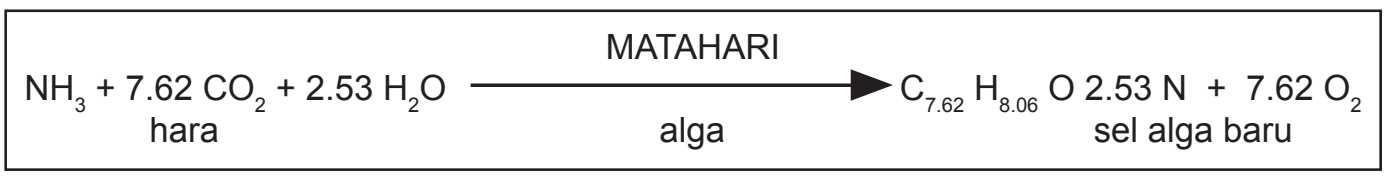

Gambar 1. Proses Fotosintesa Mikroalga 
Teknologi Lingkungan (BTL), dengan waktu pelaksanaan kurang lebih satu bulan yang meliputi preparasi limbah padat industri pengolahan rumput laut, pengamatan pertumbuhan dan analisa nutrien.

\subsection{Bahan dan Peralatan}

Untuk melakukan penelitian pemanfaatan limbah organik menjadi media kultur mikroalga, maka disiapkan media kultur standar F/2 dari Guillard disingkat FG dan media kultur yang dibuat dari limbah padat proses industri pengolahan rumput laut. Limbah padat rumput laut diperoleh dari PT. Agarindo di Pasar Kemis Tangerang. Dari limbah padat rumput laut yang sudah dikeringkan ditimbang sebanyak $1 \mathrm{~kg}$, kemudian dilarutkan dalam 20 liter akuades, setelah diaerasi selama 3 hari dan disaring, siap untuk diuji sebagai media kultur mikroalga disebut LR. Peralatan yang digunakan selama penelitian disajikan pada Gambar 2.

\subsection{Perlakuan}

Untuk mendapat gambaran bahwa media kultur asal limbah pengolahan rumput laut dapat dipakai sebagai substitusi media tumbuh mikroalga, dilakukan pengujian dengan menumbuhkan mikroalga pada media kultur asal limbah rumput laut LR dan media kultur standar $F / 2$ yang dikembangkan oleh Guillard dkk (1973) (FG) sebagai pembanding ${ }^{11)}$.

Sebagai perlakuan, disiapkan media kultur LR dan media kultur LR yang ditambahkan kedalamnya pengayaan dengan pupuk nitrogen (disingkat LRP) dengan konsentrasi nitrogen dua kali kandungan pada media FG. Selanjutnya kultur mikroalga jenis Chlorella sp. ditumbuhkan pada tiga media kultur tersebut (LR, LRP dan FG). Masing masing media kultur disiapkan dalam 3 buah Erlenmeyer sebagai ulangan.

Pengujian media tumbuh tersebut dilakukan dengan memberikan pencahayaan

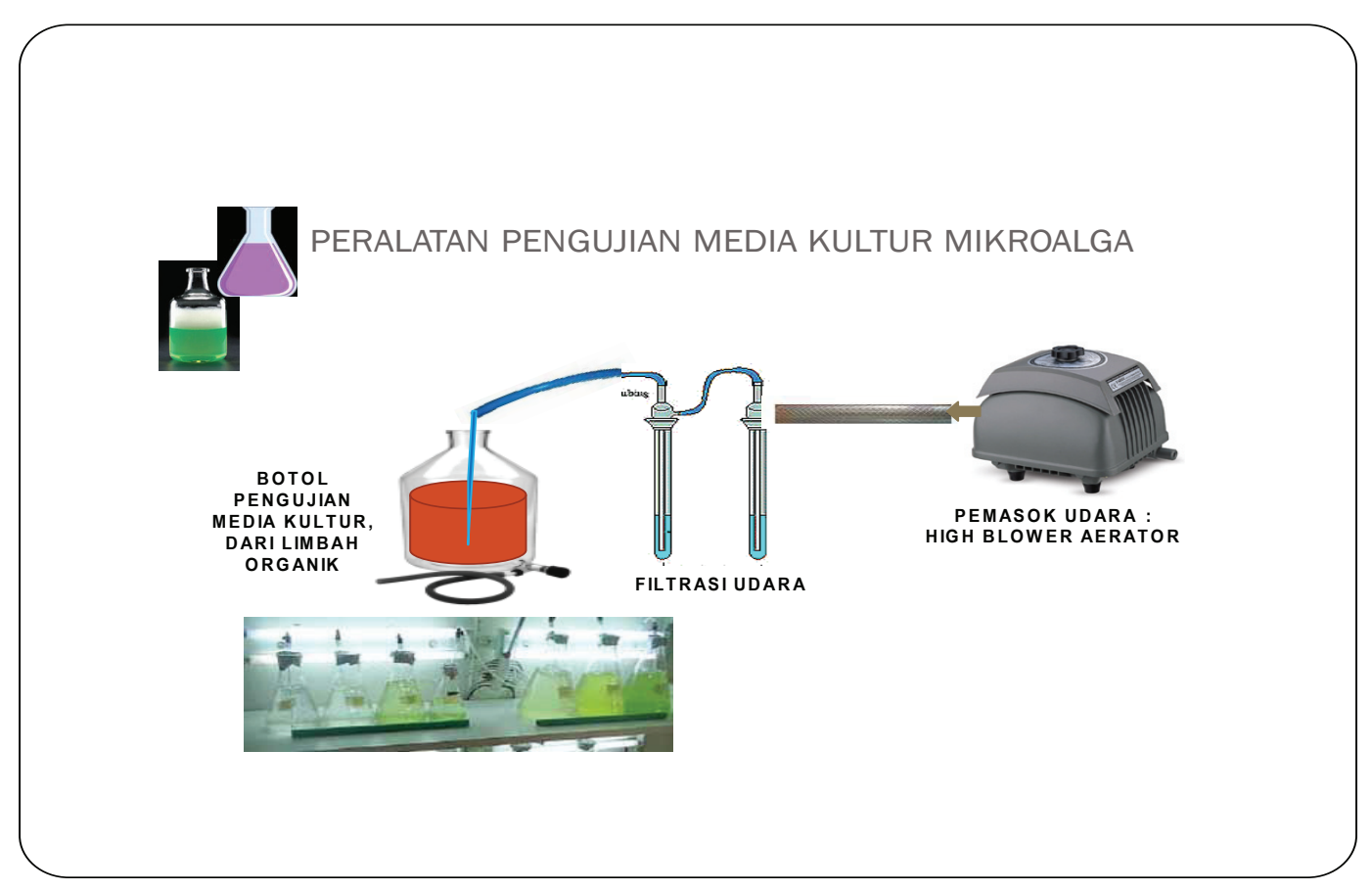

Gambar 2. Rangkaian Perlatan Uji Media Kultur Limbah RL. 
menggunakan lampu neon dengan kekuatan pencahayaan berkisar antara 3000 - 5000 lux meter dan hembusan udara luar ad libitum, selama periode pengujian berlangsung.

\subsection{Indikator}

Untuk mengetahui kandungan nutrient dari limbah padat industry pengolahan rumput laut, dilakukan uji laboratorium terhadap beberapa unusr makro dan mikro limbah tersebut, sehingga dapat diketahui sejauhmana peluang limbah tersebut untuk dimanfaatkan sebagai media tumbuh mikroalga.

Untuk mengukur perubahan yang terjadi dilakukan pengukuran terhadap Indikator perubahan kepadatan biomassa mikroalga yang ditumbuhkan dalam media kultur tersebut.

Indikator laju pertumbuhan biomassa mikroalga pada masing masing perlakuan media pertumbuhan LR, LRP dan FG, dihitung berdasarkan rumus laju pertumbuhan $(\mu)$ sebagai berikut ${ }^{12)}$ :

$$
\begin{aligned}
& \mu \quad=\operatorname{Ln}(\mathrm{Xt} / \mathrm{XO}) / \mathrm{t} \\
& \text { dimana : } \\
& \mu \quad=\text { laju pertumbuhan } \\
& \mathrm{X}_{\mathrm{t}} \quad=\text { kerapatan sel pada waktu } \\
& \mathrm{t}(\mathrm{sel} / \mathrm{ml}) \\
& \mathrm{X}_{0}=\text { kerapatan sel pada saat awal } \\
& \text { inokulasi (sel/ml) } \\
& \mathrm{t}=\text { waktu (hari) }
\end{aligned}
$$

\section{HASIL DAN PEMBAHASAN}

\subsection{Komposisi Nutrient Media FG dan LR.}

Hasil analisa laboratorium limbah padat organik industri pengolahan rumput laut menunjukkan kandungan nutrien, unsur makro dan mikro yang potensial untuk dimanfaatkan sebagai media kultur mikroalga.

Hasil analisa limbah padat tersebut menunjukkan bahwa, limbah industri pengolahan rumput laut dapat disarankan untuk digunakan dan dimanfaatkan sebagai bahan baku pembuatan media kultur mikroalga. Pemanfaatan limbah tersebut sebagai media kultur mikroalga dapat mengurangi beban biaya saat mengembangkan mikroalga secara komersial, sehingga dapat bersaing dengan bahan baku media kultur lainnya. Sebagai suatu ilustrasi, bahwa limbah tersebut mengandung beberapa jenis mikro dan makro nutrien yang diperlukan untuk pertumbuhan

\begin{tabular}{|c|c|c|c|}
\hline Bahan Kimia & Unit & $\begin{array}{c}F / 2 \\
\text { Guillard }\end{array}$ & $\begin{array}{c}\text { Limbah } \\
\text { Rumput } \\
\text { Laut }\end{array}$ \\
\hline $\mathrm{N}_{\mathrm{NaNO}_{3}}$ & $\mathrm{mg} / \mathrm{L}$ & 12.35 & 5.560 \\
\hline $\mathrm{P}_{\mathrm{NaH} 2 \mathrm{PO} 4 \mathrm{H} 2 \mathrm{O}}$ & $\mathrm{mg} / \mathrm{L}$ & 1.12 & 14.45 \\
\hline $\mathrm{Fe}_{\mathrm{FeCl} 13.6 \mathrm{H} 2 \mathrm{O}}$ & $\mathrm{mg} / \mathrm{L}$ & 0.65 & 1.70 \\
\hline $\mathrm{EDTA}_{\mathrm{Na} 2 \mathrm{EDTA} .2 \mathrm{H} 2 \mathrm{O}}$ & $\mathrm{mg} / \mathrm{L}$ & 3.40 & - \\
\hline $\mathrm{Cu}_{\mathrm{CuSO} 4.5 \mathrm{H} 2 \mathrm{O}}$ & $\mathrm{mg} / \mathrm{L}$ & 2.5 & $<0.006$ \\
\hline $\mathrm{Mo}_{\mathrm{NaMOO} 4.2 \mathrm{H} 2 \mathrm{O}}$ & $\mathrm{mg} / \mathrm{L}$ & 1.80 & $<0.70$ \\
\hline $\mathrm{Zn}_{\mathrm{ZnSO4.7H2O}}$ & $\mathrm{mg} / \mathrm{L}$ & 5 & $<0.06$ \\
\hline $\mathrm{Co}_{\mathrm{CoCl} 12.6 \mathrm{H} 2 \mathrm{O}}$ & $\mathrm{mg} / \mathrm{L}$ & 2.48 & $<0.02$ \\
\hline $\mathrm{Mn}_{\mathrm{MnCl} 2.4 \mathrm{H} 2 \mathrm{O}}$ & $\mathrm{mg} / \mathrm{L}$ & 50 & 0.87 \\
\hline B & $\mathrm{mg} / \mathrm{L}$ & - & 0.90 \\
\hline
\end{tabular}
sel mikroalga, meskipun kadarnya tidak persis sama dengan media $F / 2$ yang dikembangkan oleh Guillard dkk (1973) ${ }^{11)}$, sebagaimana disajikan pada Tabel 1.

Tabel 1.Kandungan Mikro-Makro Nutrien Media Kultur dari Limbah Padat Rumput Laut.

Nitrogen $(\mathrm{N})$. Nitrogen merupakan nutrien penting dalam proses fotosintesis mikroalga, diperlukan dalam proses metabolisme organisme bagi kelangsungan hidupnya. Oleh karena itu, kecukupan nutrien $\mathrm{N}$ potensial dan $\mathrm{N}$ terlarut ini akan menentukan laju pembelahan dan pertumbuhan sel mikroalga.

Fosfor (P). Menurut Krom et la., 1991; Nausch dan Wamund, 2004; Cortner et al, (1997); Karl (1997); dan Wu et al. (2000) dalam Komarawidjaja dkk (2010) 
7) fosfor merupakan unsur esensial bagi seluruh organisme yang membutuhkan energi untuk mentransformasi energi, membentuk membran dan menyimpan dan mereplikasi informasi genetika. Fosfor terdokumentasi sebagai unsur atau faktor pembatas pertumbuhan mikroalga.baik di laut maupun di danau. Selanjutnya menurut Cembella et al. (1984); Falkowski dan Raven, (1997) dalam Komarawidjaja dkk $(2010)^{7}$, Ketersediaan P yang rendah akan menyebabkan pengaruh pada efek biokimia dan fisiologi mikroalga. Keterbatasan $P$ yang tinggi menyebabkan mikroalga tidak mampu untuk memproduksi asam nukleat (nucleic acid) dan akhirnya berakibat pada penurunan pembentukan protein, sehingga terganggunya pembentukan sel atau pembelahan sel serta menurunnya pemanfaatan sinar matahari dan fiksasi karbon dioksida $\left(\mathrm{CO}_{2}\right)$

Ketersediaan $\mathrm{P}$ juga akan berpengaruh terhadap penyerapan unsur metal atau logam pada mikroalga. Sementara itu perubahan terhadap enzim yang berkaitan dengan logam akan mempengaruh ketersediaan $\mathrm{P}$ pada konsentrasi metal dalam sel mikroalga yang secara keseluruhan akan memepengaruhi konsentrasi $\mathrm{P}$ yang berperan dalam proses siklus logam dalam ligkungan perairan kolam maupun lautan. Banyak mikroalga menggunakan $\mathrm{P}$ organik yang ada dalam bahan organik terlarut ketika suplai $P$ inorganik sangat terbatas, demikian menurut Dyrhman et al., (2006) dalam Komarawidjaja dkk²).

Yongcheng Ji dan Robert M. Sherrelli (2008). melaporkan bahwa keterbatasan ketersediaan $\mathrm{P}$ menyebabkan berkurangnya kecepatan pertumbuhan mikroalga, ratio C:P (lebih besar dari 1800 mol molar) dan meningkatkan aktivitas Apase ${ }^{7}$.

Molibdat (Mo). Mo berperan pada aktivitas kompleks enzim nicotinamide adenine dinucleotide nitrate reductase pada mikroalga yang kekurangan nitrogen $(\mathrm{N})$. Peranan Mo dalam alga Chlorella adalah untuk mereduksi nitrat ke nitrit ${ }^{7}$.

\subsection{Pertumbuhan Mikroalga Chlorella sp. Pada Media FG}

Perubahan kepadatan Chlorella sp di media FG selama studi disajikan pada Gambar 5-4. Perubahan populasi tersebut terjadi dengan laju pertumbuhan tersaji pada Tabel 3. Gambar 4 menunjukkan bahwa sampai hari ke-4 (T-3), Chlorella sp. yang diawal studi (T-0) ditebar dengan kepadatan $35 \times 10^{3}$ sel permilliliter naik dengan pesat menjadi rata-rata $1,151 \times 10^{6}$ sel permilliliter. Ini berarti kepadatan Chlorella sp meningkat 44 kali dari kepadatan awal.

Selanjutnya Gambar 3. menunjukkan bahwa setelah naik dengan pesat, kepadatan Chlorella sp meskipun relatif kecil masih bertambah di 2 hari berikutnya dan mencapai kepadatan maksimal 1,65 x106 sel permilliliter di hari ke-6 (T-5). Setelah itu kepadatan Chlorella sp. stabil, naik turun dengan kisaran yang relatif kecil, sebelum akhirnya nampak cenderung menurun setelah dihari ke 13 (T-12). Perubahan kepadatan Chlorella sp selama studi yang diuraikan tersebut dapat disimak pada Tabel 2.

Berkenaan dengan uraian Gambar 3 dan Tabel 2 serta mempertimbangkan trend pola pertumbuhan pada media yang tidak diaerasi

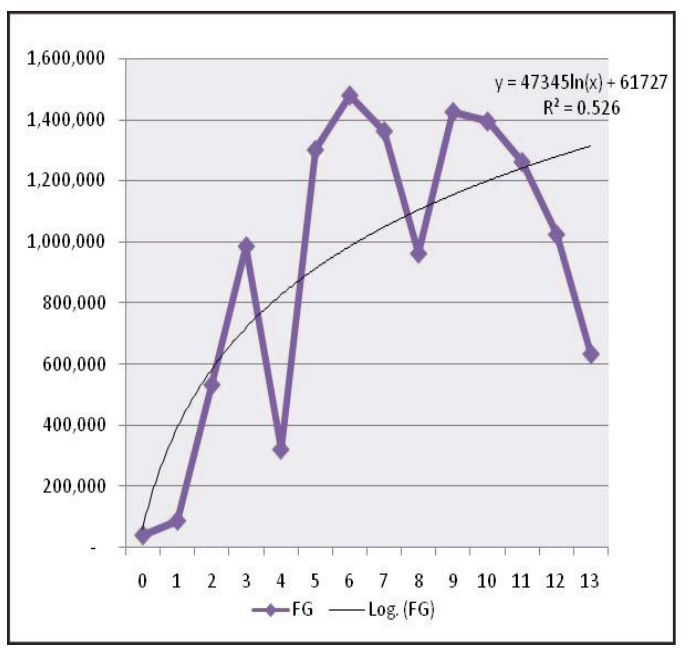

Gambar 3. Perubahan populasi Chlorella sp. di media FG 
maka dapat disimpulkan bahwa Chlorella sp. yang dikultur di media FG dengan sistem batch dan dipupuk hanya sekali diawal studi ini diduga mengalami pertumbuhan yang efektif dalam 6 hari (T-5) pertama dan memiliki daya dukung populasi Chlorella sp sebesar 1,65 x106 sel permilliliter.

Tabel 2. Laju pertumbuhan $(\mu)$ chlorella $\mathrm{sp}$. dan rasio terhadap $\mu$ diantara media FG, LR dan LRP

\begin{tabular}{|c|c|c|c|c|c|c|c|}
\hline \multirow{2}{*}{ Hari ke } & \multicolumn{3}{|c|}{ nilai $\mu$ di media: } & \multicolumn{3}{c|}{ Rasio $\mu$ media: } \\
\cline { 3 - 8 } & FG & LR & LRP & FG/LR & FG/LRP & LRP/LR \\
\hline 1 & $\mathrm{~T}_{0}$ & & & & & & \\
\hline 2 & $\mathrm{~T}_{1}$ & 0,42 & $(0,14)$ & 0,41 & $(3,0)$ & 1,0 & $(2,9)$ \\
\hline 3 & $\mathrm{~T}_{2}$ & 0,68 & 0,05 & 0,29 & 14,9 & 2,4 & 6,3 \\
\hline 4 & $\mathrm{~T}_{3}$ & 0,62 & 0,90 & 1,45 & 0,7 & 0,4 & 1,6 \\
\hline 5 & $\mathrm{~T}_{4}$ & 0,13 & 0,39 & 0,40 & 0,3 & 0,3 & 1,0 \\
\hline 6 & $\mathrm{~T}_{5}$ & 0,05 & 0,11 & 0,03 & 0,4 & 1,6 & 0,3 \\
\hline 7 & $\mathrm{~T}_{6}$ & $(0,03)$ & 0,06 & 0,03 & $(0,5)$ & $(0,9)$ & 0,6 \\
\hline 8 & $\mathrm{~T}_{7}$ & 0,03 & 0,05 & $(0,08)$ & 0,6 & $(0,4)$ & $(1,5)$ \\
\hline 9 & $\mathrm{~T}_{8}$ & $(0,15)$ & 0,08 & $(0,04)$ & $(2,0)$ & 4,0 & $(0,5)$ \\
\hline 10 & $\mathrm{~T}_{9}$ & 0,10 & 0,19 & 0,05 & 0,5 & 2,2 & 0,2 \\
\hline 11 & $\mathrm{~T}_{10}$ & $(0,04)$ & $(0,11)$ & 0,05 & 0,4 & $(0,8)$ & $(0,5)$ \\
\hline 12 & $\mathrm{~T}_{11}$ & 0,04 & 0,05 & 0,02 & 0,7 & 2,1 & 0,4 \\
\hline 13 & $\mathrm{~T}_{12}$ & $(0,24)$ & 0,10 & $(0,04)$ & $(2,5)$ & 5,3 & $(0,5)$ \\
\hline 14 & $\mathrm{~T}_{13}$ & 0,04 & $(0,13)$ & $(0,06)$ & $(0,3)$ & $(0,7)$ & 0,5 \\
\hline 15 & $\mathrm{~T}_{14}$ & 0,04 & $(0,10)$ & $(0,03)$ & $(0,4)$ & $(1,2)$ & 0,3 \\
\hline
\end{tabular}

Selama studi Chlorella sp di media FG tumbuh dengan laju pertumbuhan bervariasi antara 0,22-1,34 seperti tersaji pada Tabel 2. Secara umum, kecuali sehari setelah penebaran (t-1) laju pertumbuhan Chlorella sp dari awal hingga akhir studi menurun. Fenomena ini diduga berhubungan langsung dengan ketersediaan nutrien yang hanya diberikan diawal studi (hari pertama $=\mathrm{t}-0$ ). Pada awal kajian disaat konsentrasi nutrien tinggi dan jumlah sel Chlorella sp persatuan volume rendah maka quota nutrient setiap sel sangat tinggi, sehingga kemampuan sel untuk membelah (laju pertumbuhan) menjadi tinggi dan oleh karenanya terjadi kenaikan kepadatan yang menyolok. Sementara itu, setelah hari ke5 (t-4) Chlorella sp tumbuh dengan quota nutrien persel yang lebih rendah daripada quota sebelum $\mathrm{t}-4$, sehingga meskipun pertumbuhan lambat ini mengantarkan populasi ke kepadatan maksimal, namun tergambar dalam grafik sebagai kenaikan yang tidak menyolok.

\subsection{Pertumbuhan Mikroalga Chlorella sp. pada Media LR dan LRP}

Perubahan populasi chlorella sp di media limbah rumput laut yang tidak di pupuk (LR) dan yang di media limbah rumput laut yang dipupuk (LRP) selama studi disajikan pada Gambar 4 dan 5. Perubahan populasi mikroalga pada media LR terjadi dengan laju pertumbuhan tersaji pada Tabel 2 . Gambar 4 menunjukkan bahwa pada awal studi, yakni hari ke:1-3 Chlorella sp tidak langsung tumbuh pada media LR, sehingga kepadatannya relatif tetap dan membentuk grafik datar. Pada hari ke5 $\left(\mathrm{T}_{4}\right)$ kepadatan Chlorella sp naik sekitar 8 kali menjadi sekitar $200 \times 10^{3}$ sel permilliliter, dan dilanjutkan meningkat secara pelahan sampai mencapai kepadatan populasi tertinggi dihari ke $13\left(T_{12}\right)$ menjadi sekitar $1.270 \times 10^{3}$ sel permilliliter. Setelah hari ke 13 ini populasi nampaknya mulai berkurang, sehingga pada studi ini, kepadatan yang sekitar $1.270 \times 10^{3}$ sel permilliliter itulah yang diduga menjadi daya dukung media LR untuk Chlorella sp.

Dibandingkan pertumbuhan di media FG, pertumbuhan Chlorella sp di media LR ini memiliki masa tumbuh dan mencapai populasi tertinggi dalam periode waktu yang lebih lama, dimana di media FG dalam periode waktu 6 hari $\left(\mathrm{T}_{5}\right)$ sedangkan di media LR dalam waktu 13 hari $\left(T_{12}\right)$. Fenomena ini mengisyaratkan bahwa meskipun limbah rumput laut mengandung nitrogen dan fosfor yang tinggi, namun unsur tersebut tidak tersedia dalam kondisi siap diasimilasi, sehingga untuk diasimilasi alga perlu diurai (dekomposisi) oleh bakteria. Proses dekomposisi tersebut melepas nutrien secara bertahap, sedikit demi sedikit sehingga pertumbuhan sebagai hasil aimilasi nutrien yang terlepaspun terjadi dengan lambat sesuai dengan ketersediaan nutrien.

Satu hal yang perlu diperhatikan adalah bahwa meskipun Chlorella sp di media LR tumbuh dalam waktu yang lama, namun kepadatan tertinggi yang dicapai yakni $1.270 \times 10^{3}$ sel permilliliter masih lebih kecil 
dari kepadatan populasi yang dicapai di media FG yakni $1,653 \times 10^{3}$ sel permilliliter. $\mathrm{Hal}$ ini selain berarti bahwa daya dukung media LR untuk Chlorella sp lebih kecil daripada media $F G$, juga mengisyaratkan bahwa kualitas media LR dibawah media FG yang diduga karena rendahnya elemen $\mathrm{N}$ yang siap diasimilasi. Untuk itulah maka secara paralel dilakukan studi pemeliharaan Chlorella sp di media LR yang ditambah dengan $\mathrm{NaNO}_{3}$ sebagai pengaya nitrogen.

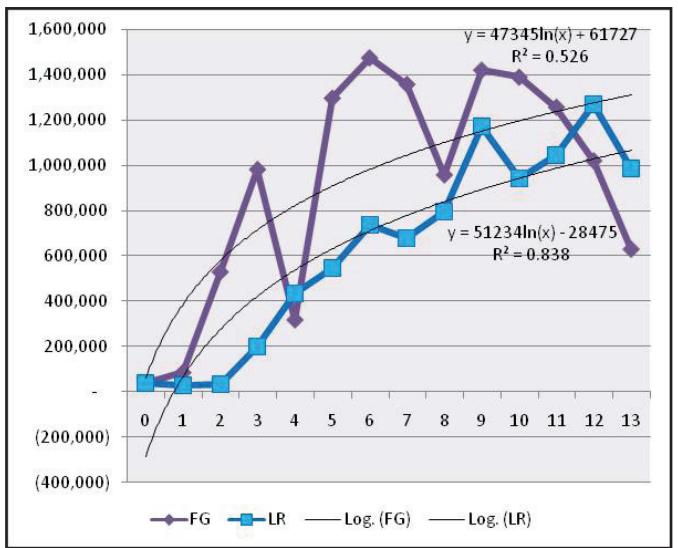

Gambar 4. Perubahan Populasi Chlorella sp. di Media LR dan LRP.

Pertumbuhan Chlorella sp di media LR yang diperkaya nitrogen yang kemudian disebut media LRP (Gambar 5) menunjukkan bahwa seperti pada media LR, Chlorella sp mulai tumbuh cepat dihari ke $5\left(\mathrm{~T}_{4}\right)$ dimana pada $\mathrm{T}_{4}$ ke $\mathrm{T}_{5}$ populasi meningkat hampir 20 kali dari $0,122 \times 106$ menjadi $2,251 \times 10^{6}$ sel permilliliter. Dihari berikutnya dari $\mathrm{T}_{5}$ ke $\mathrm{T}_{6}$ Chlorella sp masih meningkat cukup tajam yakni lebih dari 2 kali kepadatan sebelumnya hingga mencapai kepadatan $4,974 \times 10^{6} \mathrm{sel}$ permilliliter.

Setelah itu, sampai studi berakhir populasi nampak menjadi stabil, sedikit naik turun dan mencapai kepadatan maksimal sekitar $5,637 \times 10$ sel permilliliter di hari ke $13\left(\mathrm{~T}_{12}\right)$. Kepadatan tertinggi Chlorella sp di media LRP yang sekitar $5,637 \times 10$ sel permilliliter adalah jauh lebih tinggi daripada di media LR yang 1,270 x10 sel permilliliter. Perbedaan kepadatan tertinggi (daya dukung) tersebut diduga sebagai pengaruh positif penambahan $\mathrm{NaNO}_{3}$ yang berisi nitrogen siap diasimilasi. Keberadaan yang disebabkan karena penambahan nitrogen siap diasimilasi tersebut tidak hanya menyebabkan peningkatan daya dukung, namun juga telah meningkatkan laju pertumbuhan Chlorella sp diawal studi pada media LRP dimana pengaruh penambahan nitrogen- $\mathrm{NaNO}_{3}$ (Tabel 2) masih dominan.

Kepadatan tertinggi Chlorella sp di media LRP yang mencapai $5,637 \times 10$ sel permilliliter juga jauh lebih tinggi daripada di media FG yang berjumlah $1,65 \times 10^{6}$ sel permilliliter.

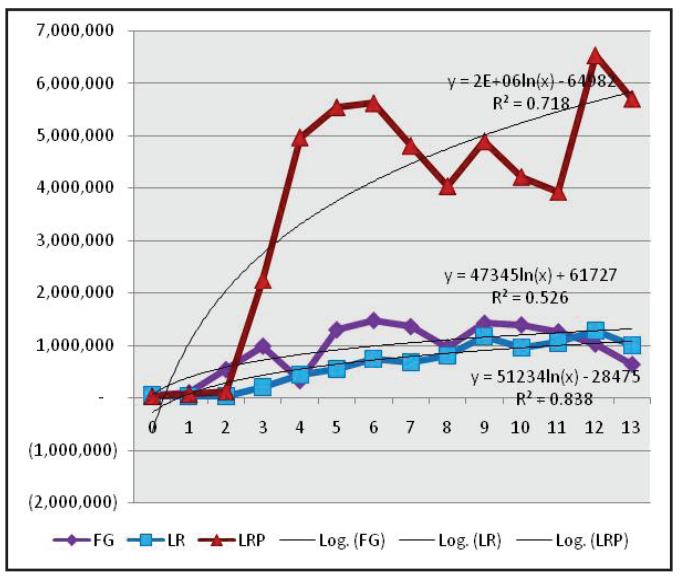

Gambar 5. Perubahan Populasi Chlorella sp. di Media FG, LR dan LRP

Selain mengungkapkan daya dukung media LRP yang lebih besar dari media $F G$, periode pencapaian yang lebih lama di media LRP $\left(T_{12}\right)$ daripada di media FG $\left(T_{5}\right)$ juga mengisyaratkan bahwa supplai nutrien di media LRP dalam periode waktu lebih lama daripada media LR, dengan kata lain media LRP memiliki kualitas yang lebih baik daripada media LR (Gambar 5). Supplai nutrien dalam periode waktu yang lebih lama tersebut diduga kuat berasal dari hasil dekomposisi limbah rumput laut oleh bakteri yang sudah berkembang.

Kecenderungan yang sama terjadi 
pula pada penelitian menggunakan limbah proses susu, sebagaimana diungkapkan olej Suberkti dkk (2010), bahwa penggunaan media FG lebih baik dari pada limbah susu (LS) sebagai media pertumbuhan Cholrella sp, sedangkan penggunaan media LS yang diperkaya (LSP) menunjukkan hasil pertumbuhan kepadatan mikroalga lebih tinggi dibanding kepadatan mikroalga pada media $F G$ dan $L S\left(\right.$ LSP>FG $>$ LS ${ }^{13}$ ).

\section{PENUTUP}

\subsection{Kesimpulan}

a. Hasil analisa laboratorium kandungan makro dan mikro nutrient limbah padat industri pengolahan rumput laut memilkiki potensi untuk dikanfaatkan sebagai media kultur mikroalga

b. Berdasarkan uji laboratorium, limbah padat proses pengolahan rumput laut mengandung makro nutrient dan beberapa mikro nutrient yang dibutuhkan dalam fotosintesis dan pertumbuhan mikroalga.

c. Kepadatan mikroalga pada media LRP $>$ FG > LR, artinya laju pertumbuhan mikroalga pada media LRP baik dibandingkan dengan media $F G$ dan LR.

\subsection{Saran}

a. Dalam mengurangi emisi yang disebabkan oleh $\mathrm{CO}_{2}$, sebaiknya pemanfaatan limbah organik lebih dioptimalkan sebagai media kultur mikroalga dalam mereduksi $\mathrm{CO}_{2}$.

b. Mengingat limbah proses pengolahan rumput laut memiliki kandungan jenis mikro nutrien yang potensial, maka kedepan perlu diusulkan untuk dilakukan kajian kombinasi dengan limbah organik lain, sehingga mampu saling melengkapi kebutuhan unsur mikro dan makro nutrient sebagai suatu media kultur.

\section{UCAPAN TERIMA KASIH}

Karya tulis ilmiah (KTI) ini merupakan bagian dari hasil riset insentif tahun 2010 yang didanai oleh pihak Dikti Kementerian Pendidikan Nasional, untuk itu ucapan terima kasih kami sampaikan. Ucapan terima kasih juga kami sampaikan kepada Prof Yudhi S Garno yang telah memberikan dorongan dalam kajian dan penyusunan naskah ini.

\section{DAFTAR PUSTAKA}

1. Santoso A D, R A Darmawan dan J P Susnto. 2011. Pengaruh Laju Alir Injeksi Gas EMISI PADA Fotobioreaktor terhadap Penyerapan $\mathrm{CO}_{2}$ oleh Chlorella sp. JTL Vol 12 No:1 : 1-6.

2. Santoso A D, R A Darmawan dan A Setiawan. 2009. Studi Kemampuan Chaetoceros $\mathrm{sp}$ dalam Penurunan Gas CO2 dalam Fotobioreaktor Sistem Batch. JHI Vol 3 No.2.

3. Chiu,S.Y., C.Y. Kao, C.H.Chen, T.C.Kuan, S.C. Ong dan C.S. Lin. 2007. Reduction of CO2 by a high-density culture of Chlorella $\mathrm{sp}$. in a semicontinuous photobioreactor. Bioresource Technology 99 (2008).pp: 3389-

4. Bishop, J.K.B. and R.E. Davis. 2000. Autonomous Observing Strategies for the Ocean Carbon Cycle.

5. Sipahutar M K. 2004. Pengurangan Bau Busuk Limbah Cair Industri Pengolahan Tepung Ikan dan Pemanfaatannya untuk Peningkatan Kelimpahan Fitoplankton Nannochloropsis. Sekolah Pascasarjana IPB. Tesisi. Tidak Dipublikasikan.

6. Anonimus. 1963. Final Report :The Uptake, Accumulation and Exchange of Radioisotopes by Open Sea Phytoplankton. The Marine Laboratory, Institute Of Marine Science, University of Miami.

7. Komarawidjaja W, Y S Garno, S W.Tjokrokusumo, H Tjahjono, dan 
R Hariyadi. 2010. Optimalisasi Pemanfaatan Limbah Organik Sebagai Substitusi Media Kultur Mikroalga Dalam Upaya Mereduksi Co2. Laporan Akhir Riset Insentif. BPPT Jakarta

8. Garno, Y.S., 1993."Respon Fitoplankton pada Perubahan Konsentrasi Nutrient terlarut", Prosiding Workshop Teknologi Lingkungan, Dit. TPLH-BPP Teknologi., 72-78 .

9. Garno, Y.S (2000): Eutrofikasi dan Pencemaran Lingkungan Perairan. Prosiding Pengelolaan Limbah dan Pemulihan Kerusakan Lingkungan, , DIT. TL. BPPT, 69-78.

10. Triwisari DA, P D Ulfana dan ADiptasari. 2009. Potensi limbah industri rumput laut sebagai bahan baku alternatif pembuatan bioetanol di Indonesia. Program Kreativitas Mahasiswa Institut Pertanian Bogor.

11. Guillard, R.R.L., 1973. Methods For Microflagellates And Nanoplankton. Handbook of Phycological Methods. Cambridge University Press, Cambridge University Press, Cambridge, pp. 8081.

12. Adil E.I., Penuntun praktikum fisiologi hewan. Jurusan Biologi FMIPA-UI, Depok, 2001, p.57.

13. Suberkti K W, H Tjahjono, W. Komarawidjaja, S.W Tjokrokusumo, 2010. Kajian pemanfaatan chlorella sebagai pengolah limbah cair dan pengendali emisi co2 industri susu. JTL ed. Khusus: 89-95. 